\title{
Spiders (Aranei) of the Belyaka Spit, Chukotka: peculiarities of the fauna and biotopic distribution
}

\author{
Пауки (Aranei) косы Бемяка, Чукотка: особенности фауны и \\ биотопического распределения
}

\author{
Olga A. Khruleva ${ }^{1}$, Andrei V. Tanasevitch ${ }^{1}$, Aleksei G. Dondua ${ }^{2}$, \\ Natalia I. Vartanyan ${ }^{2}$ \\ О.А. Хрулёва ${ }^{1}$, А.В. Танасевич ${ }^{1}$, А.Г. Аондуа ${ }^{2}$, Н.И. Вартанян ${ }^{2}$
}

\footnotetext{
${ }^{1}$ A.N. Severtsov Institute of Ecology and Evolution, Russian Academy of Sciences, Leninsky prospekt 33, Moscow 119071, Russia. Email: oa-khruleva@mail.ru; tanasevitch@gmail.com

${ }^{1}$ Институт проблем экологии и эволюции им. А.Н. Северцова РАН, Ленинский проспект 33, Москва 119071 , Россия.

${ }^{2}$ E-mail: adondya64@mail.ru
}

KEY WORDS: Russian Arctic, Chukotka Peninsula, typical tundra, chorology, habitat distribution.

КЛЮЧЕВЫЕ СЛОВА: Российская Арктика, Чукотский полуостров, типичные тундры, хорология, биотопическое распределение.

ABSTRACT. Eighteen spider species of four families have been collected by pitfall trapping from the Belyaka Spit in Kolyuchin Bay, northern coast of the Chukchi (= Chukotka) Peninsula: Linyphiidae (15 species), Lycosidae (1), Thomisidae (1) and Tetragnathidae (1). Twelve species are newly recorded from the spit. The composition of the spider fauna is typical for the northern part of the tundra zone and is characterized by predominance of purely Arctic spiders. Based on the composition of dominant species, two types of spider assemblages were revealed: 1) seaside-zone spider community in sandy-pebble habitats with halophytic vegetation, with Erigone arctica sibirica Kulczyński, 1908, Halorates holmgreni (Thorell, 1871) and H. spetsbergensis (Thorell, 1872) as predominants; 2) tundra and swamp vegetation spider community with Pardosa algens (Kulczyński, 1908) as a superdominant. The spider assemblages of wetlands are rich in species (15 species, $83 \%$ of the local araneofauna). The most typical for northern Asia hygrophilous Arctic species are presented here rather completely, including Erigone psychrophila Thorell, 1872, Hilaira vexatrix (O. Pickard-Cambridge, 1877), Hybauchenidium aquilonare (L. Koch, 1879), Masikia indistincta (Kulczyński, 1908), and Silometopoides pampia (Chamberlin, 1948), being the most abundant. The Belyaka Spit is the easternmost locality of the known distribution of Semljicola barbiger (L. Koch, 1879).

How to cite this article: Khruleva O.A., Tanasevitch A.V., Dondua A.G., Vartanyan N.I. 2018. Spiders (Aranei) of the Belyaka Spit, Chukotka: peculiarities of the fauna and biotopic distribution // Arthropoda Selecta. Vol.27. No.4. P.373-380. doi: 10.15298/arthsel. 27.4.15
РЕЗЮМЕ. На косе Беляка, расположенной в Колючинской губе на северном побережье Чукотского п-ова, почвенными ловушками собрано 18 видов пауков четырёх семейств: Linyphiidae (15 видов), Lycosidae (1), Tetragnathidae (1), Thomisidae (1); 12 видов указываются для косы впервые. Видовой состав типичен для северной части тундровой зоны, основу фауны составляют арктические виды. По набору доминантов выделено два типа группировок пауков: в приморских местообитаниях с галофитной растительностью доминируют Erigone arctica sibirica Kulczyński, 1908, Halorates holmgreni (Thorell, 1871) и H. spetsbergensis (Thorell, 1872); на участках косы с тундровой и болотной растительностью, расположенных вне зоны затопления, наиболее массовым видом является Pardosa algens (Kulczyński, 1908). Сырые местообитания косы отличает наиболее высокое видовое богатство пауков (15 видов, 83\% всей фауны); здесь весьма полно представлены арктические пауки-пигмеи, входящие в число наиболее обычных обитателей подобных стаций в северной части азиатских тундр. Особенно многочисленны Erigone psychrophila Thorell, 1872, Hilaira vexatrix (O. Pickard-Cambridge, 1877), Hybauchenidium aquilonare (L. Koch, 1879), Masikia indistincta (Kulczyński, 1908) и Silometopoides pampia (Chamberlin, 1948). Для Semljicola barbiger (L. Koch, 1879) находка на косе является самой восточной из известных точек распространения вида.

\section{Introduction}

At present, the araneofauna of tundra of the Chukchi (= Chukotka) Peninsula has been studied quite 


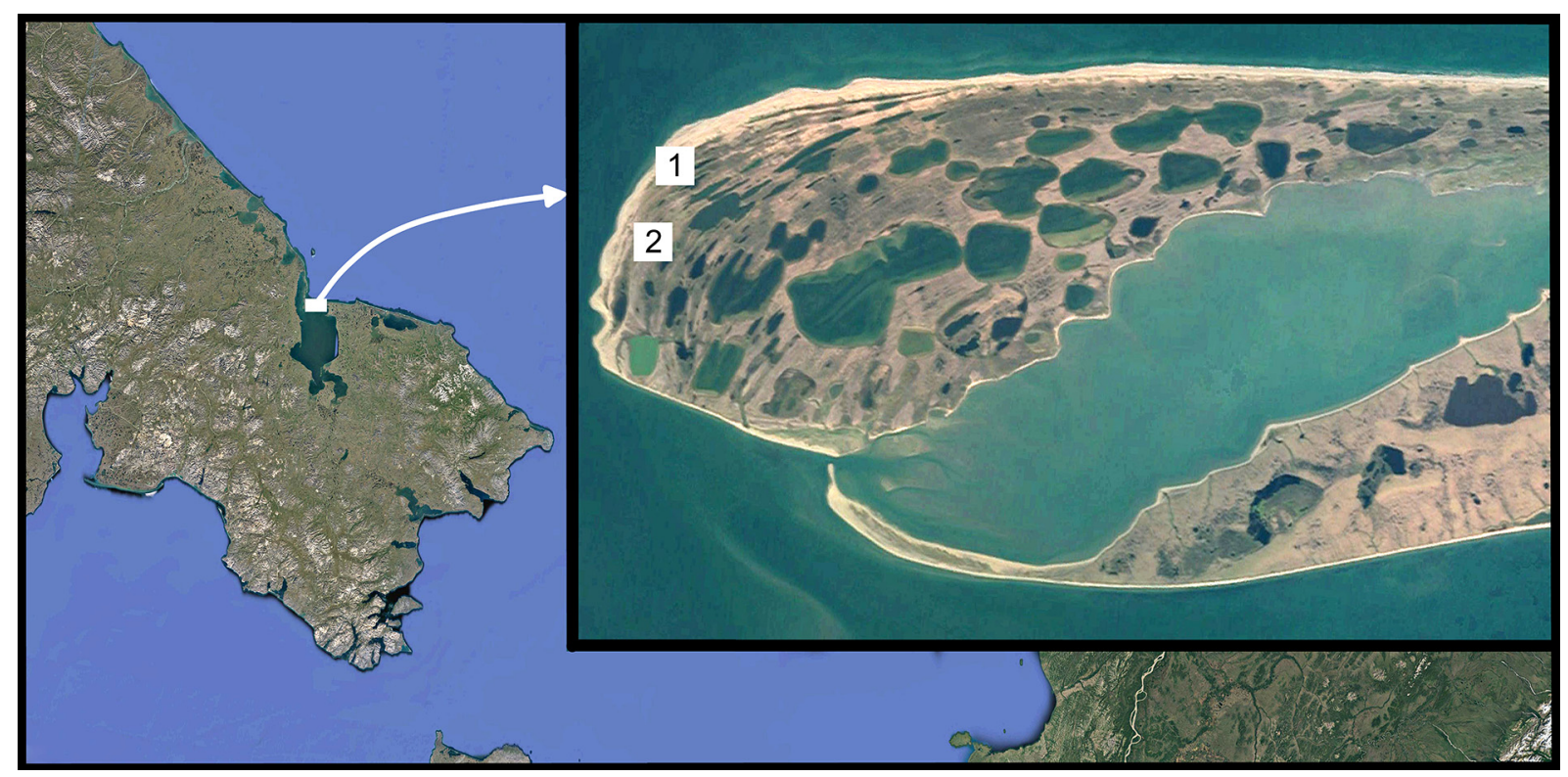

Map. Collection localities in the Belyaka Spit. 1 - biotopes No. 1 \& 2; 2 - biotopes No. 3-5.

Карта. Месторасположение точек сборов на косе Беляка. 1 - биотопы № 1 и 2; 2 - биотопы № 3-5.

insufficiently. Available data for this region are sparse, fragmentary, and virtually lack ecological information (see Eskov [1985], Marusik et al. [1992], Marusik [1993]). In this regard, any data on the composition of the local faunas, the abundance and peculiarities of preferred habitat pattern in spiders of the Chukchi tundras are of a great interest.

In 2015 , the freshly collected material on spiders was gathered from the Belyaka Spit, a narrow terrestrial stripe $21 \mathrm{~km}$ long, separating the Kolyuchin Bay and the Chukchi Sea. Based on the data of the Meteorological Station situated nearby on the Kolyuchin Island, the mean annual and July temperature is $-9.5^{\circ} \mathrm{C}$ and $6{ }^{\circ} \mathrm{C}$, respectively, while the annual precipitation is approximately $300 \mathrm{~mm}$, which is typical for the area located in the marine climate of the Arctic belt. Vegetation of this region is represented by the northern variant of hypoarctic tundra, after Yurtsev et al. [2010], which is rather corresponding to the typical tundra subzone, after Chernov [1978], Isachenko [1985], etc.

The Belyaka Spit consists of two terrestrial parts of different origin. Soils and vegetation of its southern part correspond to the continental part of the Kolyuchin Bay. The northern part of the spit (investigated area) is an alluvium, which has been formed due to the marine flow of sediments to the western direction [Kaplin et al., 1991]. The studied area is very interesting in terms of the climate severity and the young landscapes, which began to form relatively recently, 3500-4000 years ago [Ivanov, 1982]. The Belyaka Spit is in the "List of wetlands of the Northeast of Russia" due to the nesting here of the Eurasian shovel, Eurynorhynchus pygmeus (Linnaeus, 1757), the endemic of the Beringian Region.

The spider fauna of the Belyaka Spit has been only fragmentary studied. Based on the material collected by ornithologist Pavel S. Tomkovitch in 1986, seven species were recorded from that locality by Marusik et al. [1992]: Pardosa algens (Kulczyński, 1908), Diplocephalus barbiger (Roewer, 1955), Erigone arctica sibirica Kulczyński, 1908, E. psychrophila Thorell, 1872, Hilaira vexatrix (O. Pickard-Cambridge, 1877), Gibothorax tchernovi Eskov, 1989, and Estrandia grandaeva (Keyserling, 1886). All of them, except for two latter species, are represented in our recently collected material. The present paper is devoted to the analysis of composition of the local fauna and the habitat distribution of spiders in the Belyaka Spit area.

\section{Material, methods and localities}

The present paper is based on the material collected by ornithologists Aleksei Dondua and Natalia Vartanyan from the Belyaka Spit on June 14 to July 25, 2015. Pitfall traps ( $200 \mathrm{ml}$ plastic cups, filled by water) were installed in five biotopes in lines of 10 traps, and were checked every 7-10 days. In total, 1820 trap-days were made, about 1400 specimens of spiders were collected. The weather conditions of the summer season were similar to average values, the snowmelt period occurred from the end of May to the middle of June.

Five biotopes in the two sites were studied, see Map and Table 1. Their short descriptions are given below, with mentioned biotopes ordered as due to the increase in their moisture state.

Site 1 .

1. A grass meadow with Honckenya oblongifolia, Lathyrus japonicus subsp. pubescens, Senecio pseudoarnica, Leymus villossimus, etc., on sandy seashore $1.5-2 \mathrm{~m}$ in height (Fig. 1$)$. The site $\left(67^{\circ} 03^{\prime} 44.7^{\prime \prime} \mathrm{N}\right.$, $\left.174^{\circ} 36^{\prime} 27.9^{\prime \prime} \mathrm{W}\right)$ is located at $100 \mathrm{~m}$ away from the water edge, in the zone of periodic flooding. The vege- 
Table 1. Species composition, pattern of distribution and catchability of spiders (specimens/100 trapping-days) in different biotopes on the Belyaka Spit.

Таблица 1. Видовой состав, типы ареалов и уловистость пауков (экз./100 лов.-суток) в различных биотопах на косе Беляка.

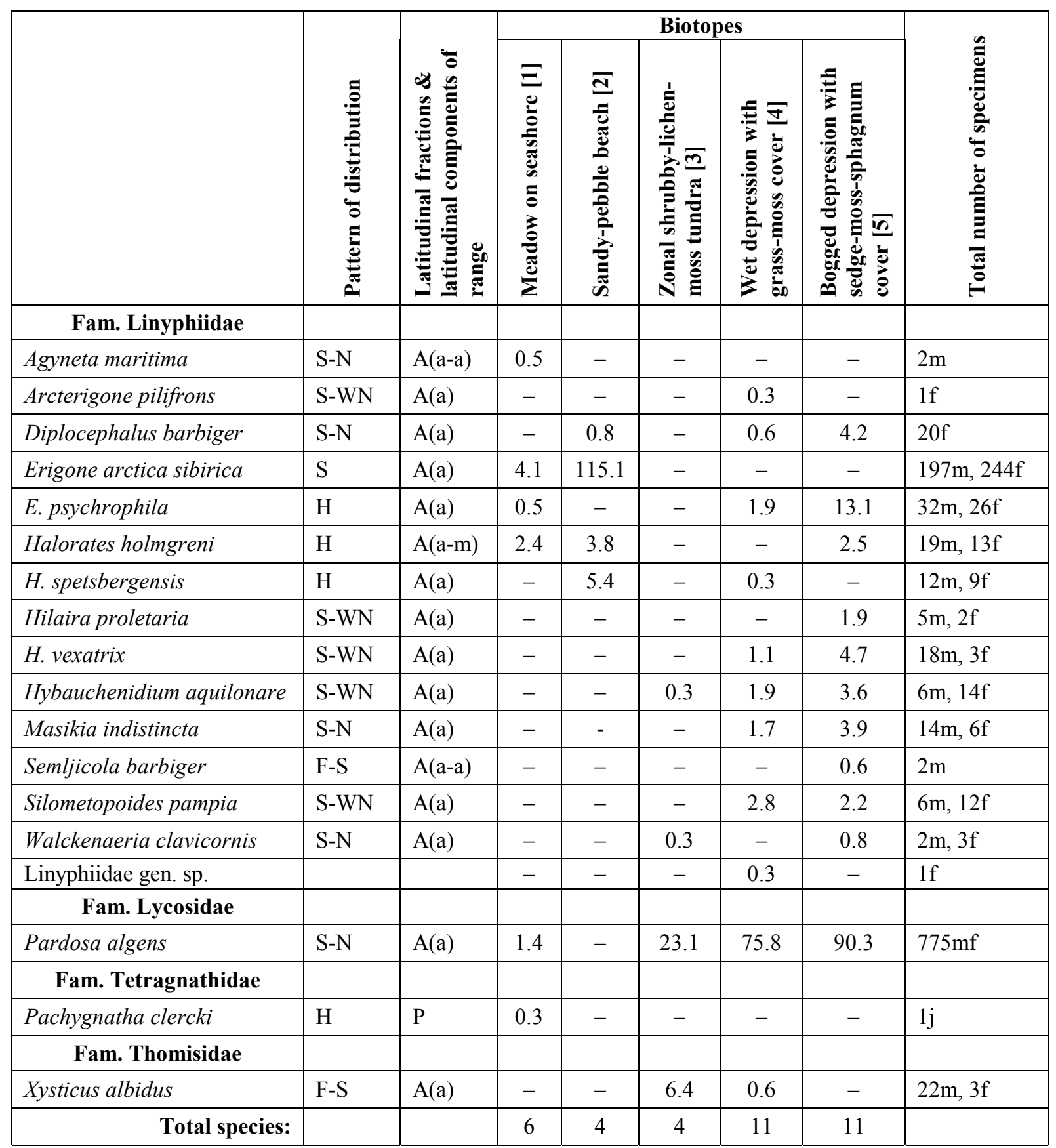

Explanation. Pattern of distribution: H - Holarctic, S-N — Siberian-Nearctic; S-WN — Siberian-West Nearctic; F-S — Fennoscandian-Siberian; S - Siberian. Latitudinal fractions: A — arctic; P — polyzonal. Latitudinal components of the range: a - arctic; a-a arcto-alpine, a-m - arcto-montane.

Условные обозначения. Типы ареалов: H - голарктический, S-N - сибирско-неарктический; S-WN - сибирскозападнонеарктический; F-S — фенноскандинавско-сибирский; S - сибирский. Широтные фракции: А — арктическая; P полизональная. Широтная составляющая ареала: a — арктический; a-a — аркто-альпийский; a-m — аркто-монтанный. 

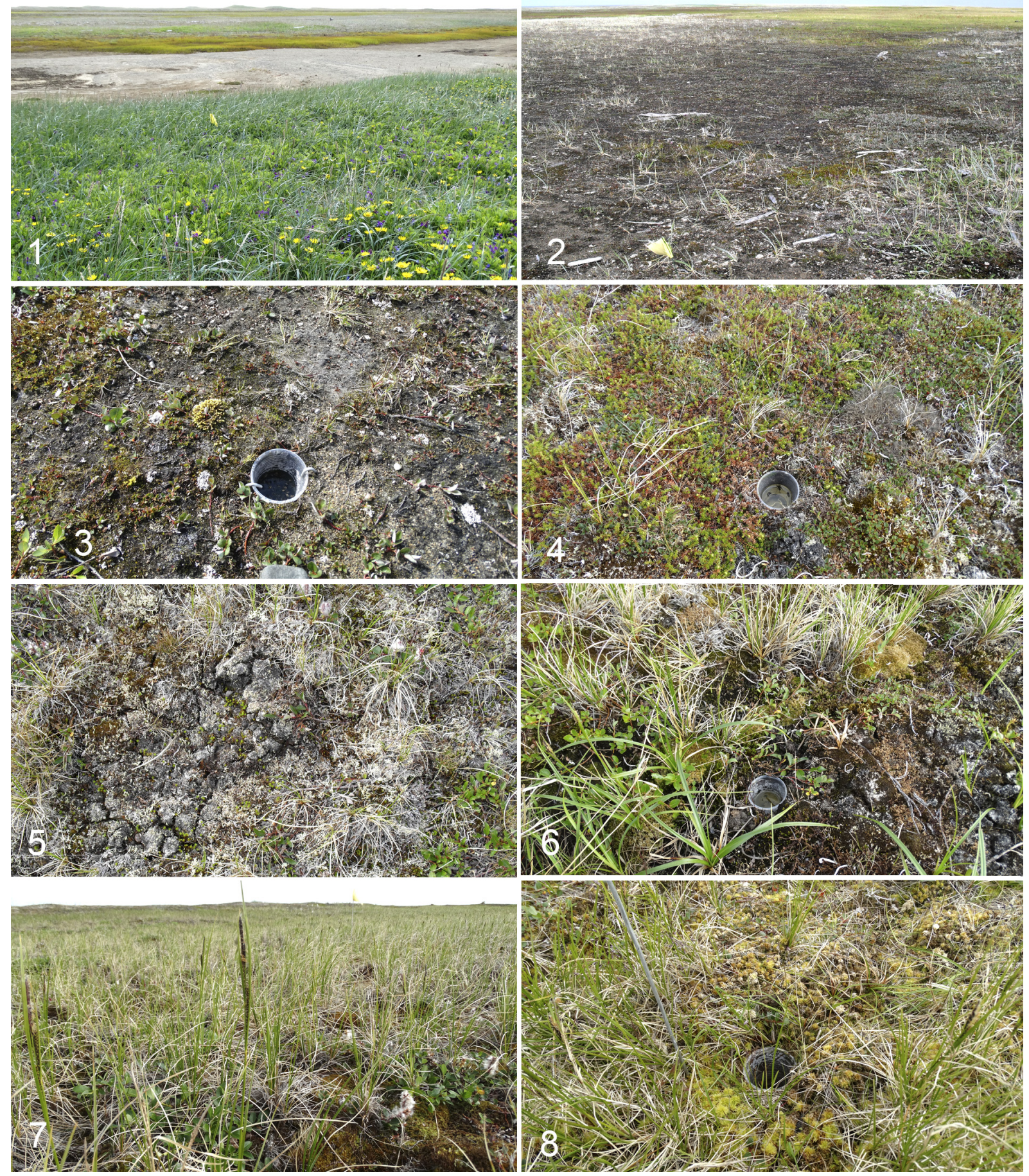

Photos 1-8. Photographs of the studied biotopes. 1 - meadow on seashore [1], general view; 2, 3 - sandy-pebble beach [2], general view and elements of plant cover; $4-5$ - zonal shrubby-lichen-moss tundra [3], elements of plant cover; 6 - wet depression with grassmoss cover [4], elements of plant cover; 7-8 - bogged depression with sedge-moss-sphagnum cover [5], general view and elements of plant cover. The biotope number is given in square brackets.

Фото изученных биотопов. 1 - луг на береговом валу [1], общий вид; 2-3 - зарастающий песчано-галечниковый пляж [2], общий вид и элементы растительного покрова; 4-5 - зональная кустарничково-моховая тундра [3], элементы растительного покрова; 6 - сырая озёрная депрессия с травяно-моховым покровом [4], элементы растительного покрова; 7-8 - заболоченная депрессия с осоково-зеленомошно-сфагновым покровом [5], общий вид и элементы растительного покрова. В квадратных скобках даны номера биотопов. 
tation cover is represented by mesohalophytic plant communities which are typical for the sandy seashores in northern Chukotka [Sergienko, 2008].

2. Sparse moss-lichen-willow communities on dry sandy-pebble beach $\left(67^{\circ} 03^{\prime} 46.0^{\prime \prime} \mathrm{N}, 174^{\circ} 36^{\prime} 08.5^{\prime \prime} \mathrm{W}\right)$ with Salix ovalifolia, S. nummularia (Figs 2, 3). This site represents the subsequent overgrowing stage of the coastal beaches. It lies in the zone of occasional flooding, traced by the old driftwood.

Site 2.

Biotopes 3-5 are located at about $500 \mathrm{~m}$ west from the previous two habitats and, despite the relative proximity to the coast (200-300 m), are outside the zone of direct marine influence. The vegetation cover of this site is typical for the tundra landscapes of northern Chukotka.

3. Grass-shrubby-lichen-moss tundra (Figs 4-5) with Carex spp., Salix spp., Empetrum subholarcticum on a moderately moist, very gentle slope of a ridge of southeastern exposure, $67^{\circ} 03^{\prime} 22.9^{\prime \prime} \mathrm{N}, 174^{\circ} 36^{\prime} 40.7^{\prime \prime} \mathrm{W}$. This variant of vegetation is a zonal-type for the area.

4. Wet depression near a lake (Fig. 6), with willowherbs cover (Salix fuscescens, Eriophorum vaginatum, Carex spp.), sphagnum and green mosses, 67 $03^{\prime}$ 22. $7^{\prime \prime} \mathrm{N}, 174^{\circ} 36^{\prime} 36.7^{\prime \prime} \mathrm{W}$.

5 . Bogged depression between two ridges with sedges, green mosses and sphagnum cover (Figs 7-8), $67^{\circ}$ $03^{\prime} 18.9^{\prime \prime} \mathrm{N}, 174^{\circ} 36^{\prime} 47.7^{\prime \prime} \mathrm{W}$.

The chorological typification is given after Tanasevitch \& Koponen [2007], Tanasevitch \& Rybalov [2010, 2015], Tanasevitch \& Nekhaeva [2016], Tanasevitch \& Khruleva [2017], etc. All species are grouped into two latitudinal fractions based on their distribution, after Tanasevitch \& Khruleva [2017]. Most species are attributed to the arctic fraction and only one represents the polyzonal group (Table 1).

\section{Results and discussion}

Unfortunately, only pitfall trapping method was used for catching spiders, and the traps were installed in a limited number of biotopes. Despite of that, 18 species of spiders were collected from the Belyaka Spit, 15 of which belonging to the family Linyphiidae. Other three families, Lycosidae, Tetragnathidae and Thomisidae, are represented by a single species each.

\section{Habitat spreading}

Most species of spiders were trapped from two, less often from three biotopes on the spit. Only five species were collected in a single biotope (Table 1). Only one species, Halorates holmgreni (Thorell, 1871), was collected in plots with different level of humidification; all the other species have sufficiently clear topical preferences. The majority of species (12) clearly prefer or are restricted by wet habitats. Spider assemblages of wetlands differ from populations of other biotopes by higher species richness (Table 1), and are quite similar to each other in the species composition and population structure: the Chekanovsky-Sörensen similarity indexes are 64 and $81 \%$, respectively. Pardosa algens is a superdominant in wet habitats, its share there was 71-87\% of all collected specimens; Diplocephalus barbiger, Erigone psychrophila, Hilaira vexatrix, Hybauchenidium aquilonare (L. Koch, 1879), Masikia indistincta (Kulczyński, 1908), Silometopoides pampia (Chamberlin, 1948) are also numerous there.

In total, 15 species were collected in wet habitats ( $83 \%$ of the local araneofauna). The total number of species in the zonal tundra was significantly lower: 4 species only. The abundance of three of them, i.e., Pardosa algens, Hybauchenidium aquilonare and Walckenaeria clavicornis (Emerton, 1882), in the zonal biotope was considerably lower than in wetlands. In contrast, the fourth species, Xysticus albidus Grese, 1909, had the highest abundance here.

The sandy seashore, the driest biotope among the surveyed ones, is characterized by the lowest pitfalltrapping catchability: only Erigone arctica sibirica and Halorates holmgreni were relatively abundant there. On the partially overgrown sandy-pebble beach, the abundance of E. a. sibirica sharply increases: 426 specimens, or $92 \%$ of the collected spiders in this biotope; both H. holmgreni and H. spetsbergensis (Thorell, 1872) being numerous there too.

\section{Distributional and ecological composition}

Spiders with the Siberian-American pattern of distribution (10 species) predominate in the araneofauna of the Belyaka Spit; other distributional groups are significantly poorer (Table 1). For Semljicola barbiger (L. Koch, 1879), the Belyaka Spit is the easternmost known locality. In the zonal aspect, the local fauna can be characterized as arctic; the optimum of the distribution of the majority of species lies in the tundra landscapes. Some of the species are unknown outside the tundra zone, e.g., Arcterigone pilifrons (L. Koch, 1879), Halorates spetsbergensis, Diplocephalus barbiger, Hilaira vexatrix, and Silometopoides pampia. Others, beside tundra zone, occur in subarctic and southern highlands [Eskov, 1985; Marusik, Eskov, 2009]. Only Erigone arctica sibirica and Hybauchenidium aquilonare show more extended, arcto-boreal pattern of distribution. However, to the south of border of the tundra zone (including forest-tundra), they are rather rare [Eskov, 1986; Esyunin, 1999; Marusik et al., 2002; Tanasevitch, Koponen, 2007; Marusik, Khruleva, 2011; Marusik, Koponen, 2015; etc.].

The list of collected species is typical for araneofaunas of the northern part of Eurasian tundras. It is very similar to that of such well-studied Arctic regional faunas as Wrangel Island [Khruleva, 2007], the lower reaches of the Lena River [Tanasevitch, Nekhaeva, 2016], the northern Yamal [Tanasevitch, Rybalov, 2015], the Yugorsky Peninsula [Tanasevitch, Khruleva, 2017]. Usually, the species-lists contain at least 12-14 common species. 
Table 2. Topical spreading of spiders in different Arctic regions of Eurasia. Таблица 2. Топическое распределение пауков в различных арктических регионах Евразии.

\begin{tabular}{|c|c|c|c|c|c|c|c|c|}
\hline & 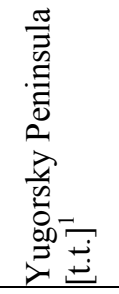 & 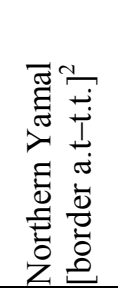 & 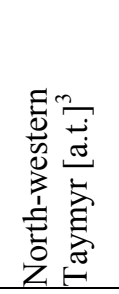 & 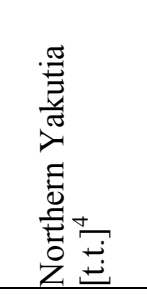 & 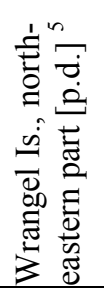 & 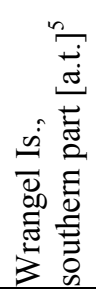 & 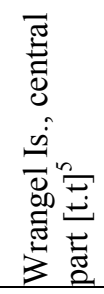 & 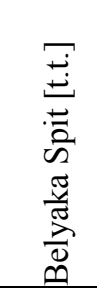 \\
\hline Agyneta maritima & - & - & - & MD & - & (D) & $\mathrm{MPr}$ & (Ps) \\
\hline Arcterigone pilifrons & M & WM & - & W (MD) & - & - & (WD) & $\mathrm{W}$ \\
\hline $\begin{array}{l}\text { Diplocephalus } \\
\text { barbiger }\end{array}$ & WM & WMPr & $\mathrm{W}(\mathrm{M})$ & $\begin{array}{l}\mathrm{WM} \\
\text { (DPr) }\end{array}$ & PsM & $\operatorname{Pr}$ & - & $\begin{array}{l}\mathrm{W} \\
(\mathrm{Ps})\end{array}$ \\
\hline $\begin{array}{l}\text { Erigone arctica } \\
\text { sibirica }\end{array}$ & - & - & - & $\begin{array}{l}\mathrm{MPr} \\
(\mathrm{DPs})\end{array}$ & - & (D) & D & Ps \\
\hline E. psychrophila & (WD) & $\begin{array}{l}\text { WPrs } \\
\text { (M) }\end{array}$ & WMD & MPr & $\begin{array}{c}\mathrm{Pr} \\
\mathrm{WM}\end{array}$ & $\begin{array}{l}\text { WPr } \\
\text { (MD) }\end{array}$ & $\operatorname{Pr}$ & $\begin{array}{l}\mathrm{W} \\
(\mathrm{Ps})\end{array}$ \\
\hline Halorates holmgreni & $\begin{array}{l}\text { DWPr } \\
(\mathrm{PsM})\end{array}$ & WMPr & - & $\operatorname{DPs}(\mathrm{M})$ & - & (M) & W & PsW \\
\hline H. spetsbergensis & W & $\mathrm{M}(\operatorname{Pr})$ & $\mathrm{D}(\mathrm{W})$ & - & $\begin{array}{l}\text { MPs } \\
(\mathrm{W})\end{array}$ & $\begin{array}{l}\mathrm{Pr} \\
\text { (D) }\end{array}$ & - & $\begin{array}{l}\text { Ps } \\
(\mathrm{W})\end{array}$ \\
\hline Hilaira proletaria & (W) & WPr & - & $\mathrm{W}$ & - & - & - & $\mathrm{W}$ \\
\hline H. vexatrix & - & - & - & - & - & $\begin{array}{c}\mathrm{W} \\
(\mathrm{MD})\end{array}$ & W & W \\
\hline $\begin{array}{l}\text { Hybauchenidium } \\
\text { aquilonare }\end{array}$ & $\mathrm{M}(\mathrm{W})$ & $(\mathrm{WM})$ & - & WMD & - & $\begin{array}{c}\text { WPr } \\
\text { M } \\
\text { (D) }\end{array}$ & - & $\mathrm{W}(\mathrm{M})$ \\
\hline Masikia indistincta & (W) & WMPr & - & $\begin{array}{l}\text { WM } \\
(\operatorname{Pr})\end{array}$ & - & - & - & W \\
\hline Semljicola barbiger & $\begin{array}{l}\text { MW } \\
\text { (D) }\end{array}$ & $\begin{array}{l}\text { WPr } \\
(\mathrm{M})\end{array}$ & - & W & - & - & - & (W) \\
\hline $\begin{array}{l}\text { Silometopoides } \\
\text { pampia }\end{array}$ & - & WPr & - & (MD) & - & WPr & W & W \\
\hline $\begin{array}{l}\text { Walckenaeria } \\
\text { clavicornis }\end{array}$ & $\begin{array}{l}\text { M (W, } \\
\text { Ps) }\end{array}$ & WMPr & $\begin{array}{l}\text { MD } \\
(\mathrm{W})\end{array}$ & $\mathrm{MD}(\mathrm{Pr})$ & - & $\begin{array}{l}\mathrm{M} \\
\text { (D) } \\
\end{array}$ & (M) & $(\mathrm{WM})$ \\
\hline Pachygnatha clerki & $\mathrm{W}(\mathrm{Ps})$ & WMPr & - & $\mathrm{WM}(\mathrm{Ps})$ & - & - & - & (Ps) \\
\hline Pardosa algens & - & - & - & - & - & W & $\begin{array}{c}\mathrm{Pr} \\
\mathrm{WMD} \\
\end{array}$ & $\begin{array}{l}\text { WM } \\
\text { (Ps) }\end{array}$ \\
\hline Xysticus albidus & MD & (M) & - & (MD) & - & - & WMD & $\begin{array}{c}\mathrm{M} \\
\text { (W) }\end{array}$ \\
\hline
\end{tabular}

Explanation. Biotopes: W — wetlands; M — habitats with moderate moisture; D — dry habitats; Pr — pebble and sandy-pebble river floodplains; Ps — seaside pebble and sandy-pebble beaches; in brackets — single records. Used sources: ${ }^{1}$ Tanasevitch \& Khruleva [2017]; ${ }^{2}$ Tanasevitch \& Rybalov [2015]; ${ }^{3}$ Khruleva \& Berezin [2002]; ${ }^{4}$ Tanasevitch \& Nekhaeva [2016]; ${ }^{5}$ Khruleva [1987, 1991; our unpublished data]. In square brackets it is shown the zonal position of the area: p.d. — polar desert, a.t. — arctic tundra subzone, t.t. — typical tundra subzone.

Условные обозначения. Местообитания: W - сырые; M - умеренно увлажнённые; D - сухие; $\mathrm{Pr}$ - галечниковые и песчано-галечниковые поймы рек; Ps — приморские галечниковые и песчано-галечниковые пляжи; в скобках указаны единичные находки вида. Использованные источники: ${ }^{1}$ Tanasevitch \& Khruleva [2017]; ${ }^{2}$ Tanasevitch \& Rybalov [2015]; ${ }^{3}$ Khruleva \& Berezin [2002]; ${ }^{4}$ Tanasevitch \& Nekhaeva [2016]; ${ }^{5}$ Хрулёва [1987, 1991; наши неопубликованные данные]. В квадратных скобках указана зональная приуроченность района исследования: p.d. — полярные пустыни; а.t. — подзона арктических тундр; t.t. — подзона типичных тундр. 
Data on the topical preferences of spiders in various Arctic tundra regions are shown in Table 2. In the northern part of the tundra zone, most of the species collected from the Belyaka Spit inhabit different types of biotopes. Almost all of them occur in sandy-pebble plots in floodplains of rivers or sea coasts in various tundra regions (Table 2). This fact presupposes that they have an obvious potential to colonize the sea spits too. Preference of such stations is especially characteristic for Erigone arctica sibirica, Halorates holmgreni and $H$. spetsbergensis, the species, which form the core of the spider assemblages in the Belyaka Spit beaches. In other regions of the Arctic these species occur both on the sea coasts and in the interior, mainland regions, where they show very high abundance in some places in river floodplains, less often on gravelly slopes with sparse vegetation, see Khruleva [1987, 1991], Khruleva \& Berezin [2002], Tanasevitch \& Rybalov [2015], Tanasevitch \& Nekhaeva [2016], Tanasevitch \& Khruleva [2017].

Most of the species collected from the Belyaka Spit in different Eurasian tundras prefer wet habitats, i.e., Arcterigone pilifrons, Diplocephalus barbiger, Erigone psychrophila, Hilaira proletaria (L. Koch, 1879), $H$. vexatrix, Hybauchenidium aquilonare, Masikia indistincta, Silometopoides pampia, Pardosa algens, Pachygnatha clercki Sundevall, 1823. In contrast, spiders inhabiting moderately moist or dry stations, except for Agyneta maritima (Emerton, 1919), are not represented in the treated material.

Surprisingly, the typical for the arctic tundra mesophilous spiders like Alopecosa mutabilis (Kulczyński, 1908), Hilaira gertschi Holm, 1960, H. glacialis (Thorell, 1871), Oreoneta leviceps (L. Koch, 1879), or Semljicola arcticus (Eskov, 1989), have not been collected on the Belyaka Spit.

The main peculiarities of the araneocomplexes in the Belyaka Spit

The peculiarities of spider habitat distribution in the Belyaka Spit reflect well their topical preferences as a whole. Species that occur on seashores in other regions of the Arctic, e.g., Diplocephalus barbiger, Erigone arctica sibirica, Halorates holmgreni, $H$. spetsbergensis, Pachygnatha clercki, etc., were collected in habitats with pronounced marine influence. The main part of the spider population of these biotopes (71$99 \%$ of all collected specimens) is represented by species, which prefer sand and pebble substrates. In contrary, in sward habitats outside the flooding zone, dominant species are those preferring wet communities. Their proportion in the population is from $77 \%$ in the site with moderate moistening, to $98-99 \%$ in wet depressions.

Probably, the similar pattern of spider distribution in the studied area does not depend of the degree of salinity of the surveyed biotopes. For example, E. arctica sibirica and $H$. holmgreni inhabiting seaside beaches occur in the interior regions of Wrangel Island [Khru- leva, 1987] and Taimyr [Osipov, 2003]. On the contrary, hygrophilous species, e.g., Masikia indistincta and Silometopoides pampia, abundantly inhabit the saline maritime marches of Dolgyi Island [Marusik et al., 2016]. Obviously, the distribution of these species depends rather on the moistening regime and substrate: the presence of bare ground spots and the well-developed moss cover, the latter being the most important factor for spiders habitation [Tanasevitch et al., 2009].

As mentioned above, the main feature of the spider distributions on the Belyaka Spit is restriction of most species to moist plots. Judging by the available data, in the Eurasian sector of the Arctic, i.e., arctic tundra subzone and the northern part of the typical tundra subzone, the core of araneocomplexes in wetlands contains about 20 purely arctic linyphiid species, see Khruleva [1987, 1991]; Khruleva \& Berezin [2002]; Tanasevitch \& Rybalov [2015]; Tanasevitch \& Khrisanova [2016]; Tanasevitch \& Nekhaeva [2016]; Tanasevitch \& Khruleva [2017]. Based on our unpublished data, the list of species which are particularly specific for wetlands in the eastern part of the Asiatic tundra is as follows: Diplocephalus barbiger, Erigone psychrophila, Gibothorax tchernovi, Halorates holmgreni, Hilaira incondita L. Koch, 1879, H. nivalis Holm, 1937, H. proletaria, H.vexatrix, Hybauchenidium aquilonare, Masikia indistincta, Praestigia groenlandica Holm, 1967, Semljicola barbiger, S. simplex (Kulczyński, 1908), and Silometopoides pampia from Linyphiidae, and Pardosa septentrionalis (Westring, 1861), P. algens and (or) P. podhorskii (Kulczyński, 1907) from Lycosidae. Notably, almost two-thirds of the mentioned above species have been collected from investigated area in two biotopes only, which shows their high activity in the region. Probably, the extremal local environments are rather favorable for these species and lie within their ecological optimum.

Thus, the following features are characteristic for the araneocomplexes of the Belyak Spit: 1) The core of spider population is composed by arctic species which can inhabit a wide range of biotopes, but clearly prefer wetlands or coastal habitats.

2) The composition of specific dominants clearly shows the presence of two different kinds of spider assemblages. The first one is typical for coastal halogen habitats, the second one is specific for sites with zonal-tundra and wetlands vegetation, located outside of area of direct sea influence.

3) The main peculiarity of the spider assemblages of wet habitats is their high diversity in the species composition. The most typical for northern Asia hygrophilous arctic species are presented here especially fully.

Acknowledgments. This work was supported in part by the Russian Foundation for Basic Research, grant No. 15-04-05964A, and the programs of the Fundamental Research of the RAS Presidium "Biodiversi- 
ty and Natural Resources of Russia", "Evolution of the Organic World. The role and influence of planetary processes".

\section{References}

Chernov Yu.I. 1978. [The structure of the animal population of the Subarctic]. Moscow: Nauka Publ. 165 pp. [in Russian]

Eskov K.Y. 1985. [Spiders of the tundra zone of the USSR] // Ovcharenko V.I. (ed.). Fauna i ekologiya paukov SSSR. Trudy Zool. Inst. AN SSSR. Leningrad. Vol.139. P.121-128 [in Russian].

Eskov K.Y.1986. [Fauna of spiders (Aranei) of the hypoarctic belt of Siberia] // Yuzhnye tundry Taimyra. Leningrad: Nauka Publ. P.174-191 [in Russian].

Esyunin S.L. 1999. [The structure and diversity of the population of spiders of the zonal and mountain tundra of the Urals] // Zool. Zhurn. Vol.78. No.12. P.1822-1832 [in Russian, English summary].

Isachenko A.G. 1985. [Landscapes of the USSR]. Leningrad: Leningrad State University. 320 pp. [in Russian]

Ivanov V.F. 1982. [Fluctuations in sea level near the shores of Eastern Chukotka in the Late Pleistocene and Holocene] // Kolebaniya urovney morey i okeanov za 15000 let. Moscow: Nauka. P.190-195 [in Russian].

Kaplin P.A., Leontyev O.N., Lukyanova S.A., Nikiforov L.G. 1991 [Shores]. Moscow: Mysl' Publ. 479 pp. [in Russian]

Khruleva O.A. 1987. [Invertebrates] // Fauna zapovednika "Ostrov Vrangelya". Moscow: VINITI. P.6-36 [in Russian].

Khruleva O.A. 1991. [Spatial aspects of the population of invertebrate animals of Wrangel Island] // Amirkhanov A.M. (ed.) Populyatsii i soobshchestva zhivotnykh ostrova Vrangelya Moscow. P.161-179 [in Russian].

Khruleva O.A. 2007. [Peculiarity of terrestrial Arthropod fauna in view of Environment of the Wrangel Island] // A.R. Gruzdev (ed.). Priroda ostrova Vrangelya. Sovremennye issledovaniya. St. Petersburg: Asterion Publ. P.136-175 [in Russian]

Khruleva O.A., Berezin M.V. 2002. Arthropod availability // Willems F., Turnhout C. van, Kleef H. van \& Felix R. (eds.). Breeding birds of Medusa Bay, Taimyr, Russia. Methods for biological monitoring in the Arctic with results of 1998 and 1999, WIWO-report 77, Foundation WIWO, Zeist. P.79-100.

Marusik Yu.M. 1993. [Terrestrial invertebrates] // Berman D.I. (ed.). Ekologiya basseyna reki Amguemy. Part 1. Vladivostok. P.164-185 [in Russian].

Marusik Yu.M., Eskov K.Y. 2009. Spiders (Arachnida: Aranei) of the tundra zone of Russia // S.I. Golovatch, O.L. Makarova, A.B. Babenko, L.D. Penev (eds.). Species and communities in extreme environments. Festschrift towards 75 th anniversary and a laudatio in honour of Academician Yuri Ivanovich Chernov. Sofia-Moscow: Pensoft Publishers \& KMK Sci. Press. P.131-164.
Marusik Yu.M., Eskov K.Y., Kim J.P. 1992. A check list of Spiders (Aranei) of Northeast Asia // Korean Arachnology. Vol.8. No.1-2. P.129-158.

Marusik Yu.M., Khrulyova O.A. 2011. First data on spiders and harvestmen (Arachnida: Aranei \& Opiliones) from the Karaginski island, Eastern Koryakia, Kamchatka Peninsula // Arthropoda Selecta. Vol.20. No.4. P.323-329.

Marusik Yu.M., Koponen S. 2015. New biogeographical records of spiders and harvestmen (Arachnida: Aranei \& Opiliones) from West Siberia, including an annotated list of spiders // Entomologica Fennica. Vol.26. P.165-170.

Marusik Yu.M., Koponen S., Makarova O.L. 2016. A survey of spiders (Araneae) collected on the arctic island Dolgiy $\left(69^{\circ} 12^{\prime} \mathrm{N}\right)$, Barents Sea // Arachnology. Vol.17. No.1. P.1024.

Marusik Yu.M., Koponen S., Vinokurov N.N., Nogovistyna S.N. 2002. Spiders (Aranei) from northernmost forest-tundra of northeastern Yakutia $\left(70^{\circ} 35^{\prime} \mathrm{N}, 134^{\circ} 34^{\prime} \mathrm{E}\right)$ with a description of three new species // Arthropoda Selecta. Vol.10 (for 2001). No.4. P.351-370

Osipov D.V. 2003. [Structure of the spider (Aranei) fauna in southern tundra of western Taimyr] // Zool. Zhurn. Vol.82. No.10. P.1266-1270 [in Russian, English summary].

Sergienko L.A. 2008. [Flora and vegetation of the coasts of the Russian Arctic and adjacent territories]. Petrozavodsk. 225 pp. [in Russian]

Tanasevitch A.V., Khrisanova M. 2016. First data on spiders (Aranei) from arctic territories of Gydan Peninsula, Russia // Arthropoda Selecta. Vol.24. No.1. P.115-118.

Tanasevitch A.V., Khruleva O.A. 2017. Spiders (Aranei) of the typical tundra subzone of the Yugorsky Peninsula, Russia // Arthropoda Selecta. Vol.26. No.4. P.341-368.

Tanasevitch A.V., Koponen S. 2007. Spiders of the southern tundra in the Russian Plain // Arthropoda Selecta. Vol.15. No.4. P.295-345.

Tanasevitch A.V., Nekhaeva A.A. 2016. Spiders (Aranei) of the Kharaulakh Mountains and the Lena River lower reaches, northern Yakutia, Russia // Arthropoda Selecta. Vol.25. No.3. P.307326.

Tanasevitch A.V., Rybalov L.B. 2010. On spiders from tundra zone of Kola Peninsula, Russia (Arachnida, Aranei) // Arthropoda Selecta. Vol.19. No.1. P.41-56.

Tanasevitch A.V., Rybalov L.B. 2015. Fauna and distribution of spiders (Aranei) of the arctic tundra in northern Yamal Peninsula, Russia // Arthropoda Selecta. Vol.24. No.2. P.215-230.

Tanasevitch A.V., Rybalov L.B., Kamayev I.O. 2009. [Soil macrofauna population dynamics in a zone of technogenic impact] // Lesovedenie. No.6. P.63-72 [in Russian, English summary].

Yurtsev B.A., Koroleva T.M., Petrovsky V.V., Polozova T.G., Zhukova P.G., Katenin A.E. 2010 // [Konspekt flory Chyukotskoi tundry]. St.-Petersburg: VVM Ltd Publ. 628 pp. [in Russian].

Responsible editor K.G. Mikhailov 